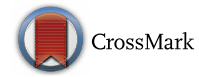

\section{Estimating gross primary productivity of a tropical forest ecosystem over north-east India using LAI and meteorological variables}

\author{
Pramit Kumar Deb Burman ${ }^{1, *}$, Dipankar Sarma ${ }^{2}$, Mathew Williams $^{3}$, \\ AnANDAKUmar Karipot ${ }^{4}$ and Supriyo Chakraborty ${ }^{1}$ \\ ${ }^{1}$ Centre for Climate Change Research, Indian Institute of Tropical Meteorology, Pune 411 008, India. \\ ${ }^{2}$ Department of Environmental Sciences, Tezpur University, Tezpur 784 028, India. \\ ${ }^{3}$ School of Geosciences, University of Edinburgh, Edinburgh EH9 3FF, UK. \\ ${ }^{4}$ Department of Atmospheric and Space Sciences, Savitribai Phule Pune University, Pune 411 00\%, India. \\ ${ }^{*}$ Corresponding author. e-mail: pramit.cat@tropmet.res.in
}

MS received 5 January 2017; revised 10 April 2017; accepted 13 April 2017; published online 6 October 2017

Tropical forests act as a major sink of atmospheric carbon dioxide, and store large amounts of carbon in biomass. India is a tropical country with regions of dense vegetation and high biodiversity. However due to the paucity of observations, the carbon sequestration potential of these forests could not be assessed in detail so far. To address this gap, several flux towers were erected over different ecosystems in India by Indian Institute of Tropical Meteorology as part of the MetFlux India project funded by MoES (Ministry of Earth Sciences, Government of India). A $50 \mathrm{~m}$ tall tower was set up over a semi-evergreen moist deciduous forest named Kaziranga National Park in north-eastern part of India which houses a significant stretch of local forest cover. Climatically this region is identified to be humid sub-tropical. Here we report first generation of the in situ meteorological observations and leaf area index (LAI) measurements from this site. LAI obtained from NASA's Moderate Resolution Imaging Spectroradiometer (MODIS) is compared with the in situ measured LAI. We use these in situ measurements to calculate the total gross photosynthesis (or gross primary productivity, GPP) of the forest using a calibrated model. LAI and GPP show prominent seasonal variation. LAI ranges between 0.75 in winter to 3.25 in summer. Annual GPP is estimated to be $2.11 \mathrm{~kg} \mathrm{C} \mathrm{m}^{-2}$ year $^{-1}$.

Keywords. Gross primary productivity (GPP); leaf area index (LAI); aggregated canopy model (ACM); Moderate Resolution Imaging Spectroradiometer (MODIS); tropical forest; MetFlux India.

\section{Introduction}

Fluxnet is a global network of the micrometeorological towers (Baldocchi et al. 2001) erected over multiple different ecosystems distributed over a wide latitudinal area from $77^{\circ} \mathrm{N}$ to $57^{\circ} \mathrm{S}$ for continuous measurement of energy, water and greenhouse gas (GHG) fluxes between the biosphere and the atmosphere (https://fluxnet. ornl.gov/fluxnetdb). Continental and regional scale networks such as AmeriFlux (Boden et al. 2013), AsiaFlux (Mizoguchi et al. 2009), ICOS (https:// www.icos-ri.eu/), Ozflux (Beringer et al. 2016), etc., exist as part of this broad program which archive and share the quality-controlled data for the scientific community. Main objectives of this 
coordinated effort are to find out the global sources and sinks of GHG and ecosystem exchange patterns of energy and water vapour, to provide data for improving the land-surface processes in the models and validate the satellite products. It also aims to find out the carbon sequestration potential of the major vegetations scattered over the globe (Baldocchi et al. 2001).

Gross primary productivity (GPP) is a key ecosystem parameter for understanding carbon assimilation. GPP is the rate of photosynthetic conversion of $\mathrm{CO}_{2}$ to organic carbon by plants per unit surface area (Chapin et al. 2006). GPP has been estimated from upscaling leaf level flux measurements (Williams et al. 1996) or by analysing net ecosystem flux data (Grace et al. 1996; Curtis et al. 2002; Saigusa et al. 2005). These estimates are used for calibrating and validating model simulations of GPP and its variation at multiple spatial and temporal scales (Coops et al. 2007; Jung et al. 2011; El-Masri et al. 2013; Barman et al. 2014). Different land-surface models have been enhanced by comparing their predicted GPP against Fluxnet observations (Bonan 1995; Sellers et al. 1997; Bonan et al. 2011; Schaefer et al. 2012). Several researchers have calculated GPP using radiation parameters such as PAR (Photosynthetically Active Radiation) and LUE (Light Use Efficiency) (Garbulsky et al. 2010; Wu et al. 2011). Data products from different satellites such as Moderate Resolution Imaging Spectroradiometer (MODIS), Landsat, etc., have also been used to predict the GPP of different biomes (Turner et al. 2003; Gitelson et al. 2012).

Leaf Area Index (LAI) is a dimensionless vegetation index, which is a strong constraint on GPP. For a broadleaf canopy, it is defined as the total one-sided leaf surface area per unit ground area (Watson 1947). It controls radiation and precipitation interception by the canopy, microclimate within the canopy and water and $\mathrm{CO}_{2}$ exchange between the canopy and the atmosphere. Thus it plays a crucial role in estimating GPP and is one of the primary components for process-based land-surface biogeochemical models (Bréda 2003). There are multiple techniques to estimate LAI including satellite observation (Gower et al. 1999), airborne measurements (Solberg et al. 2009) and ground-based direct and indirect measurements (Jonckheere et al. 2004). Several studies exist where LAI measurements conducted at various Fluxnet sites have been used for estimating GPP (Chen et al. 2006; Muraoka et al. 2010).
South Asia (SA) ranks among the most densely populated regions in the world. It is located in the tropical belt and the terrestrial ecosystems over this region are considered as highly active for $\mathrm{CO}_{2}$, water vapour, sensible and latent heat exchanges. Terrestrial ecosystems are believed to be one of the most potent sinks of atmospheric carbon dioxide (Le Quéré et al. 2009, 2015). Specifically, tropical forests act as major sinks for carbon (Schimel et al. 2001). India is the largest country located in SA. It is the second most populated nation in the world recording a fast economic growth over last few decades. Geographically it is bound by the Himalayas in the north, the Bay of Bengal in the east, the Arabian Sea in the west and the Indian Ocean in the south. Multiple different landscapes and ecosystems exist across India ranging from evergreen coniferous to deciduous forests. Being an agrarian country, India also has a vast spread of irrigated and non-irrigated agricultural lands. However, due to the paucity of observations $\mathrm{CO}_{2}$, water vapour and energy exchanges over these ecosystems could not be studied systematically in detail until recently when a network was proposed to be set up along the lines of Fluxnet (Sundareshwar et al. 2007). Earlier, this lack of ground-based measurements compelled the researchers to use satellite-based $\mathrm{CO}_{2}$ and LAI values for estimating GPP and NPP (Net Primary Productivity) (Chabra and Dadhwal 2004; Nayak et al. 2013). However, presence of the towering convective clouds in the tropical region makes satellite estimation of $\mathrm{CO}_{2}$ difficult. It is often constrained by the observations from the neighbouring regions. Moreover, lack of sufficient numbers of surface measurements of $\mathrm{CO}_{2}$ fluxes result in non-validation of satellite products (Takagi et al. 2011; Valsala et al. 2013). As part of NCP (National Carbon Project) by ISRO (Indian Space Research Organization) several eddy covariance (EC) flux towers were set up. Measured fluxes were used in conjunction with the MODIS surface temperature and reflectance data to calculate GPP over a wheat field in north India (Patel et al. 2011). In other related studies, flux and climate data were analyzed over mixed deciduous forests in central India (Jha et al. 2013), north India (Watham et al. 2014) and mangrove forest in Gangetic delta in east India (Rodda et al. 2016). In some cases, these studies calculated the GPP using site level observations. However, none of these studies have reported GPP estimation using site level observations of LAI and its variations. 


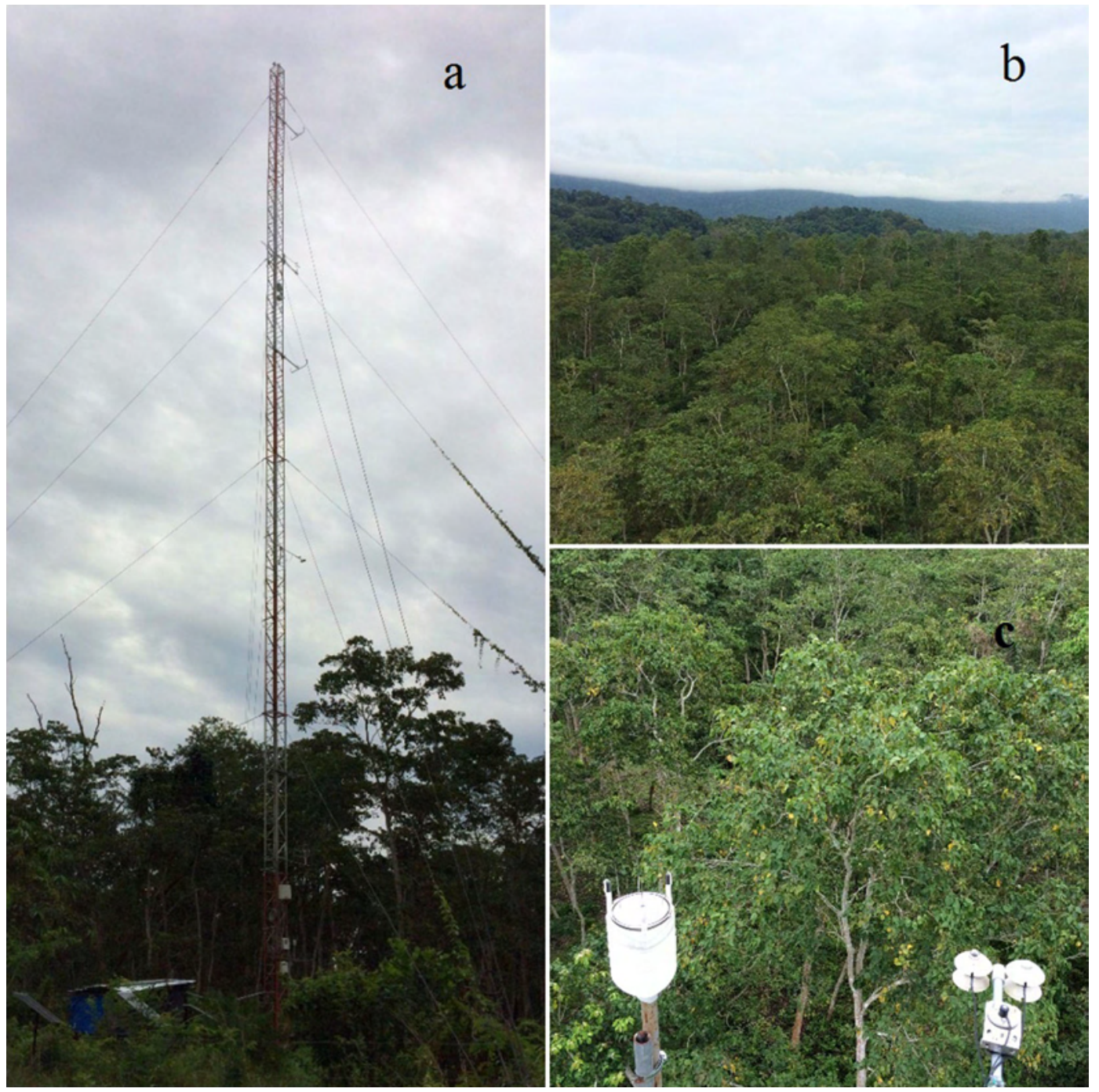

Figure 1. (a) $50 \mathrm{~m}$ tall micro-meteorological tower at KNP; (b) deciduous forest canopy at KNP as seen from the tower; (c) multi-component weather sensor and net radiometer over the vegetation canopy as seen from the tower.

Kaziranga National Park (KNP) is a forest located in a pristine location far from the major human settlement at Tezpur in north-eastern state of Assam in India. Local climate in this region is classified as humid sub-tropical (CWa type) according to the Köppen climate classification. A $50 \mathrm{~m}$ tall micro-meteorological tower was erected in 2014 by IITM (Indian Institute of Tropical Meteorology, Pune) in collaboration with Tezpur University as part of MetFlux India, an MoES (Ministry of Earth Sciences, Government of India) funded project in this forest (figure 1a) for longterm monitoring of GHG fluxes including $\mathrm{CO}_{2}$ and water vapour. Geographical location of this tower is approximately at $26^{\circ}, 37^{\prime} \mathrm{N}$ and $93^{\circ}, 21^{\prime} \mathrm{E}$. The tower is located at a semi-evergreen moist deciduous tall forest canopy of an average height of $20 \mathrm{~m}$. This tower is instrumented at multiple levels to measure weather parameters, radiation components and eddy covariance fluxes (figure $1 \mathrm{~b}$ and c). Additional sensors have been used for soil parameters. LAI variation in this forest has not been reported so far. In the only available earlier work, satellite derived NDVI (Normalized Difference Vegetation Index) data which is related to LAI were analyzed over north-east India (Saikia 2009).

The Aggregated Canopy Model (ACM) is a simple canopy photosynthesis model which calculates daily GPP from available meteorological datasets (Williams et al. 1997). It is derived from a processbased model named Soil-Plant-Atmosphere (SPA) which acts at a much finer time scale (Williams et al. 1996). GPP predicted by SPA was first validated successfully for a temperate deciduous forest against available EC data. It was then 
tested and calibrated globally for multiple different ecosystems, climatic conditions and driving variables (Fisher et al. 2006, 2007). Main advantages of ACM are its requirement of a minimal number of input variables to run and its inherent ability to operate at fine temporal scale. Most of the process-based models require $\mathrm{CO}_{2}$ and $\mathrm{H}_{2} \mathrm{O}$ data at half-hourly or hourly frequency. However, continuous field measurements at such high frequency are very difficult and often not achieved. ACM can act successfully in such cases to bridge the gap between the coarse scale measurements and the GPP. In the present study, ACM has been used to estimate daily and annual GPP at KNP.

This paper has threefold scientific objectives. For a sub-tropical forest in India, we quantified the variations of air temperature and radiation during a 1-year long observation period. Second, we determined the seasonal leaf phenology at the forest, and compared this to earth observations from MODIS, a satellite product. Finally, we assess the carbon sequestration potential of the forest canopy using a global calibrated ecological model.

\section{Data and methods}

\subsection{Data}

Air temperature was sampled every $1 \mathrm{~min}$ by WXT520 multi-component weather sensor manufactured by Vaisala Oyj at our observational site at KNP at four different heights at 4, 7, 20 and $37 \mathrm{~m}$. Incoming and outgoing short-wave and long-wave radiation was measured at $20 \mathrm{~m}$ every $1 \mathrm{~min}$ by NR01 net radiometer made by
Hukseflux. Additionally, half-hourly averaged records were created from both of this raw data files. The raw and averaged data files were stored in CR-3000 data-logger by Campbell Scientific. LI-7200 enclosed-path $\mathrm{CO}_{2} / \mathrm{H}_{2} \mathrm{O}$ Infra-Red Gas Analyzer (IRGA) by LI-COR was used to sample the $\mathrm{CO}_{2}$ concentration in atmosphere at a frequency of $10 \mathrm{~Hz}$ at $37 \mathrm{~m}$. This record was stored in a separate data-logger by LI-COR inc. Wind components were measured by a sonic anemometer Windmaster Pro by Gill Instruments, UK. The raw concentrations and wind data were subjected to rigorous quality control measures such as despiking (Vickers and Mahrt 1997), detrending (Kaimal and Finnigan 1994a) and co-ordinate rotations (Kaimal and Finnigan 1994b) in EddyPro software (version 6.2.0) by LI-COR (https://www. licor.com). EddyPro produces half-hourly averaged $\mathrm{CO}_{2}$ mole fraction in $\mu \mathrm{mol} \mathrm{mol}{ }^{-1}$ (or ppm) as one of its output. This represents the amount of $\mathrm{CO}_{2}$ present per unit amount of the moist air. The calculation assumes that the moisture has not been subtracted from the air which makes it suitable to be used as the atmospheric $\mathrm{CO}_{2}$ concentration. LAI was measured twice a week at KNP using the hand-held LAI-2200 Leaf-Area/Plant Canopy Analyzer manufactured by LI-COR. For each LAI measurement, three above-canopy and 12 belowcanopy readings were taken around the tower location. Finally, a single LAI value was calculated from these by internal algorithms of LAI-2200 and stored in its in-built memory. LAI value calculated this way is an average representation of the surrounding plant canopy. A detailed summary about all the variables and measuring instruments used in the present study have been listed in table 1 .

Table 1. Variables used in the present study.

\begin{tabular}{|c|c|c|c|c|}
\hline Variable & Abbreviation & Unit & $\begin{array}{l}\text { Measuring instrument/ } \\
\text { sensor, manufacturer }\end{array}$ & $\begin{array}{c}\text { Measurement } \\
\text { height }(\mathrm{m})\end{array}$ \\
\hline Air-temperature & $\mathrm{T}$ & ${ }^{\circ} \mathrm{C}$ & $\begin{array}{l}\text { WXT520 multi-component } \\
\text { weather transmitter, } \\
\text { Vaisala }\end{array}$ & 37 \\
\hline $\begin{array}{l}\text { Incoming short-wave } \\
(\mathrm{SW}) \text { radiation }\end{array}$ & ISR & $\mathrm{W} \mathrm{m}^{-2}$ & $\begin{array}{l}\text { NR-01 4-component net } \\
\text { radiometer, Hukseflux }\end{array}$ & 20 \\
\hline $\mathrm{CO}_{2}$ concentration & $\mathrm{c}$ & $\mu \mathrm{mol} \mathrm{mol}{ }^{-1}$ & $\begin{array}{l}\text { LI-7200 enclosed path } \\
\mathrm{CO}_{2} / \mathrm{H}_{2} \mathrm{O} \text { analyzer, } \\
\text { Licor inc. }\end{array}$ & 37 \\
\hline Leaf-Area Index & LAI & $\mathrm{m}^{2} \mathrm{~m}^{-2}$ & $\begin{array}{l}\text { LAI-2200 Leaf-Area/Plant } \\
\text { Canopy Analyzer, Licor inc. }\end{array}$ & Ground level \\
\hline
\end{tabular}


In the present work, daily average values of air temperature at $37 \mathrm{~m}$, incoming solar radiation and $\mathrm{CO}_{2}$ concentration have been calculated from their half-hourly records using $\mathrm{R}$ which is an open-source software (https://www.r-project.org/). Daily maximum and minimum values of air temperature at $37 \mathrm{~m}$ have also been sorted out which have further been used in the calculation of daily temperature. Few of the records had missing values which have been removed. Polynomial fits to LAI and GPP have been produced in OriginPro 8 .

MODIS collection 6 data contains six scientific data layers namely FPAR, LAI, quality control (QC) and standard deviations for FPAR and LAI. Terra and Aqua combined FPAR/LAI data collection is abbreviated as MCD15A3H. It is available at a spatial resolution of $500 \mathrm{~m}$ and temporal resolution of 4 days. Sinusoidal grid tilling is applied to this set of data making the spatial resolution at equator to be $10^{\circ}$ by $10^{\circ}$. Entire data over the globe is sub-divided into 648 tiles where each line of constant latitude has 36 tiles and each line of constant longitude has 18 tiles. More details about this data product can be found in the MOD15 user guide. Data is downloaded in hdf-eos (Hierarchical Data Format - Earth Observation System) format from Earthdata search client (https://search. earthdata.nasa.gov/). It is then further processed in MatLab. Only the data contained in the tile no. h26v06 has been used as this tile encompasses KNP. LAI values over the geographical location of $26^{\circ}, 37^{\prime} \mathrm{N}$ and $93^{\circ}, 21^{\prime} \mathrm{E}$ has been extracted from this tile along with the associated QC flag. Good quality data produced by the RT algorithm have been retained and bad quality data using backup algorithm or filling values have been filtered out. Satellite data retrieval often gets contaminated due to the presence of clouds especially in the tropical regions (Gao et al. 2008). Hence only the data during the clear sky condition have been used.

\subsection{Model}

The Aggregated Canopy Model (ACM) has been used to calculate daily and annual GPP in our work. This model requires 10 input variables to run, namely, LAI (in $\mathrm{m}^{2} \mathrm{~m}^{-2}$ ), average daily temperature $\left(T_{\text {avg }}\right.$ in $\left.{ }^{\circ} \mathrm{C}\right)$, range of daily temperature $\left(T_{\text {range }}\right.$ in ${ }^{\circ} \mathrm{C}$ ), foliar $N$ concentration (nitro in $\mathrm{gN} \mathrm{m}^{-2}$ ), total daily short-wave irradiance ( $I$ in MJ $\left.\mathrm{m}^{-2} \mathrm{~d}^{-1}\right)$, leaf-soil water potential difference $\left(\psi_{d}\right.$ in $\left.\mathrm{MPa}\right)$, atmospheric $\mathrm{CO}_{2}$ concentration $(c$ in $\mu \mathrm{mol} \mathrm{mol}{ }^{-1}$ or ppm), day of year (DOY), latitude (lat in ${ }^{\circ} \mathrm{N}$ ) and total plant-soil hydraulic resistance $\left(R_{\text {tot }}\right.$ in $\mathrm{MPa} \mathrm{m}{ }^{2} \mathrm{~s}$ mili $\left.\mathrm{mol}^{-1}\right)$. More details about these parameters including their acceptable range of variation can be found in Williams et al. (1997). Among all these parameters LAI, $T_{\text {avg }}, T_{\text {range }}, I$ and $c$ were measured at our site at KNP. Values of nitro, $\psi_{d}$ and $\mathrm{R}_{\text {tot }}$ were prescribed as the requisite observations were not available.

\subsection{Satellite observations of LAI}

NASA's Earth Observing System (EOS) is one of the most effective platforms that produces global map of the biophysical parameters such as NDVI, FPAR (Fraction of Photosynthetically Active Radiation), LAI, etc., in a regular fashion. LAI measurements are produced since June 2000 from the surface reflectance data of Moderate Resolution Imaging Spectraradiometer (MODIS) (Myneni et al. 2002). Primary LAI/FPAR algorithm of MODIS is based on a look-up-table (LUT) based procedure that exploits the spectral informations contained in MODIS red $(648 \mathrm{~nm})$ and near-infrared $(858 \mathrm{~nm})$ surface reflectances. It is also known as the RT (radiative transfer) algorithm (Knyazikhin et al. 1998). It has another backup algorithm which uses the phenomenological relationships among LAI , FPAR and NDVI in association with a global biome classification map (Yang et al. 2006). MODIS LAI dataset has been subjected to many extensive validation studies over multiple different ecosystems, such as croplands (Garrigues et al. 2008), forest (Aragão et al. 2005; Fisher and Mustard 2007; Liang et al. 2011; Tang et al. 2014), etc. In these works, quality controlled MODIS LAI data has been checked against in situ LAI measurements, such as LAI-2000, lidar remote sensing, digital hemispherical photography, etc., to improve the applicability and interpretation of MODIS LAI data. However, despite the application of improved retrieval algorithm and filtering techniques, significant mismatch exists between site measured and MODIS LAI (Biudes et al. 2014). In present work, a 1-year long time series of LAI has been extracted over KNP from MODIS Terra and Aqua combined data product. This has been plotted along with the in situ measured LAI for comparing their performances in capturing the seasonal variations in the canopy coverage. 


\section{Results and discussions}

Very first generation of the atmospheric measurements at KNP have been used in the present work. It is first of its kind considering the fact that no such prior study exists over north-east India till date.

\subsection{Air temperature and radiation}

In this work, a 1-year long observation period during 01st July, 2015 to 30th June, 2016 has been considered. Time series of multiple atmospheric variables measured during this period have been plotted in the subsequent figures as explained below. Air-temperature $(T)$ is sampled every min and a $30 \mathrm{~min}$ averaged record is produced from the same. Average $\left(T_{\mathrm{avg}}\right)$, maximum $\left(T_{\max }\right)$ and minimum $\left(T_{\min }\right)$ air-temperature have been sorted out for each day from this record. Daily range of airtemperature is defined as $T_{\text {range }}=\left(T_{\max }-T_{\min }\right) / 2$. $T_{\text {avg }}$ and $T_{\text {range }}$ for each day have been plotted in figure 2. Incoming and outgoing components of both short-wave (SW) and long-wave (LW) radiation are recorded at KNP every min and a 30 min averaged record is generated from the same. Daily average of incoming SW radiation (ISR) is calculated from this record. Total daily SW irradiance ( $I$ in $\mathrm{MJ} \mathrm{m} \mathrm{m}^{-2} \mathrm{~d}^{-1}$ ) is calculated from the same using the following unit conversions, i.e., $1 \mathrm{~d}=(24 \times 3600) \mathrm{s}$ and $1 \mathrm{~W}=10^{-6} \mathrm{MJ} \mathrm{s}^{-1}$. Hence, $1 \mathrm{~W} \mathrm{~m}^{-2}=1 \mathrm{~J} \mathrm{~m}^{-2} \mathrm{~s}^{-1}=10^{-6} \mathrm{MJ} \mathrm{m}^{-2} \mathrm{~s}^{-1}=$ $10^{-6} \times 3600 \times 24 \mathrm{MJ} \mathrm{m}^{-2} \mathrm{~d}^{-1}$. I is plotted in figure 3 .

$T$ varies within $25-30^{\circ} \mathrm{C}$ since the beginning of July to the end of September in 2015. It records a gradual decrease since the starting of October, 2015 and dips to a minimum of $12^{\circ} \mathrm{C}$ during the middle of January, 2016. Gradually it starts increasing again to reach a maximum value of $30^{\circ} \mathrm{C}$ at the end of June, 2016. $I$ is seen to be more during July-September in 2015. It starts decreasing gradually since the starting of October, 2016 and dips to minimum in the middle of January, 2016. I starts increasing after that and reaches maximum again after May, 2016. Such variations in $T_{\text {avg }}$ and $I$ are expected and in well coherence with each other. Northern hemisphere receives more ISR during boreal summer which spans from June to September each year. As a result atmospheric air-column gets warmer. However, day-to-day variations in $I$ and $T$ during this period can be attributed to frequent occurrences of cloud and rainfall events as

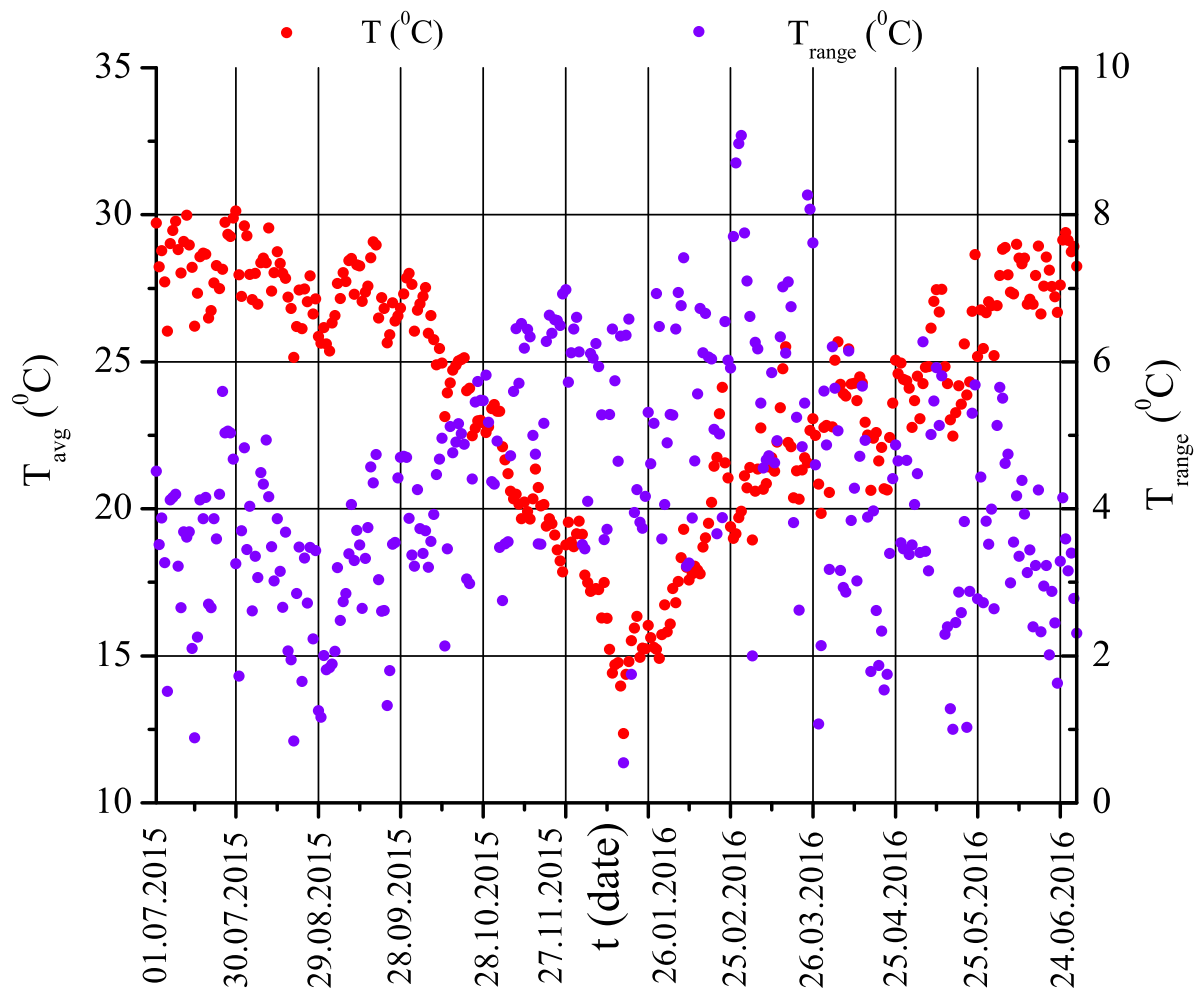

Figure 2. Observed daily mean and range of air temperature in red and violet, respectively during 1 st July, 2015 to 30 th June, 2016. 


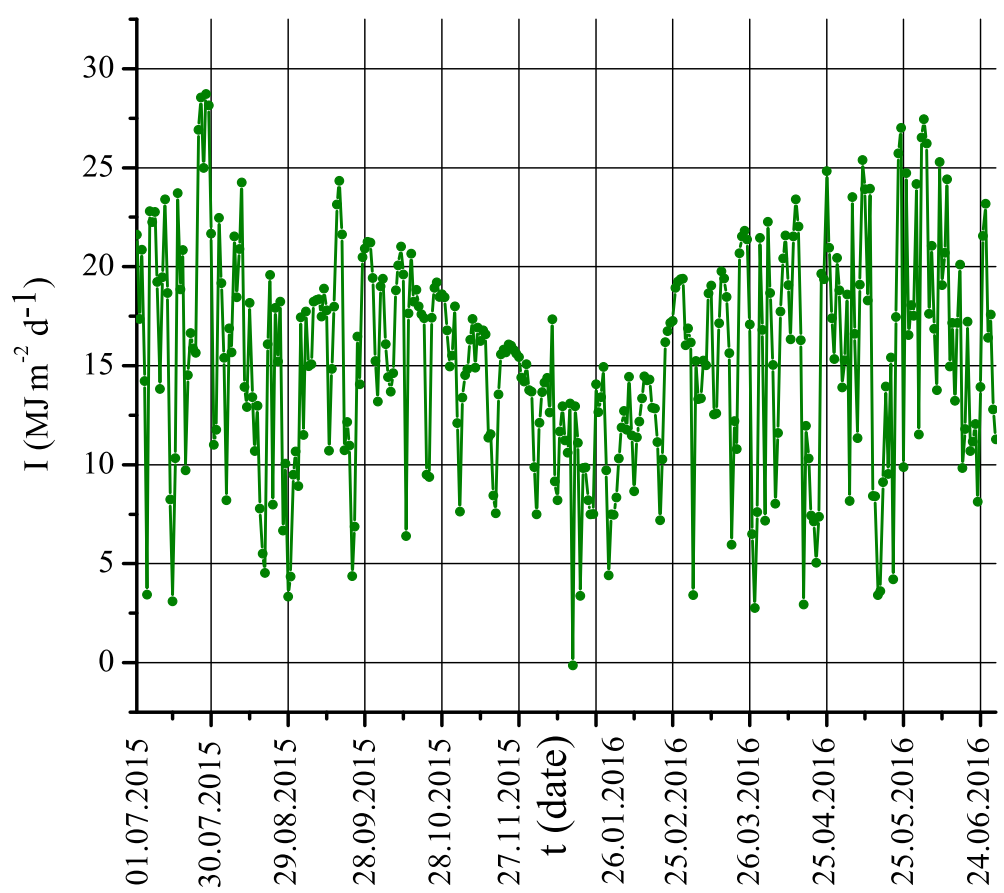

Figure 3. Observed daily averaged incoming short-wave radiation during 1st July, 2015 to 30th June, 2016.

this is the time Indian sub-continent experiences Indian summer monsoon (ISM). Monsoon recedes after September each year. Hence, $T$ shows a decreasing pattern during October and November in annual cycle. This period is considered as post-monsoon. During boreal winter (DecemberFebruary), northern hemisphere receives less ISR and hence atmospheric air-column cools. Again, it starts receiving more ISR from March. March to May is considered as pre-monsoon period during which Indian landmass starts getting warmer due to receiving more solar insolation. This results in reversal of land-sea temperature gradient and initiates ISM. A detailed discussion of ISM is well beyond the scope of present work although.

\section{$3.2 \mathrm{CO}_{2}$ concentration}

The $\mathrm{CO}_{2}$ concentration $(c)$ in the ambient air is measured at a frequency of $10 \mathrm{~Hz}$ at KNP using LI-7200. From this record daily average values of $c$ have been calculated and plotted in figure 4 . Due to malfunctioning of the data-logger, $\mathrm{CO}_{2}$ values could not be stored from 20th December, 2015 to 14th January, 2016.

$\mathrm{CO}_{2}$ is seen to decrease gradually from $450 \mu \mathrm{mol} \mathrm{mol}^{-1}$ at the beginning of July to $420 \mu \mathrm{mol} \mathrm{mol}^{-1}$ till the end of September, 2015.
During October and November in the same year, it does not monotonically increase or decrease. However, it fluctuates within a range of 420-400 $\mu \mathrm{mol} \mathrm{mol}{ }^{-1}$. Further decrease in $c$ is recorded from $405 \mu$ mole mole ${ }^{-1}$ on 15 th January to $380 \mu$ mol mol ${ }^{-1}$ on 30th March in 2016. It fluctuates around $380 \mathrm{\mu mol} \mathrm{mol}^{-1}$ in April, 2016. However, it starts increasing from the beginning of May in 2016. Till the end of June 2016, c reaches up to $400 \mu \mathrm{mol} \mathrm{mol}^{-1}$. These are above canopy $c$ values as $c$ is measured at a height of $37 \mathrm{~m}$ while average canopy height is $20 \mathrm{~m}$. Hence, $c$ bears the signature of the vegetation canopy and soil underneath. During ISM, Indian landmass receives an ample amount of rainfall. Due to this, water content in the soil increases. Wet soil has less $\mathrm{CO}_{2}$ holding capacity than dry soil (Harper et al. 2005). Moreover, increased microbial and decomposing activities are observed in wet soil (Sponseller 2007). As a result of these, enhanced $\mathrm{CO}_{2}$ emission could be observed from the soil during the beginning of ISM, i.e., in the starting of June. It helps in increasing the $\mathrm{CO}_{2}$ concentration in the atmosphere. However, $I$ and ISR are also larger during ISM compared to other times of the year. These render the soil and environment conducive for plant growth. As a result, enhanced photosynthetic activity is observed during these months. It results in a gradual decrease in the atmospheric $\mathrm{CO}_{2}$ concentration. During 


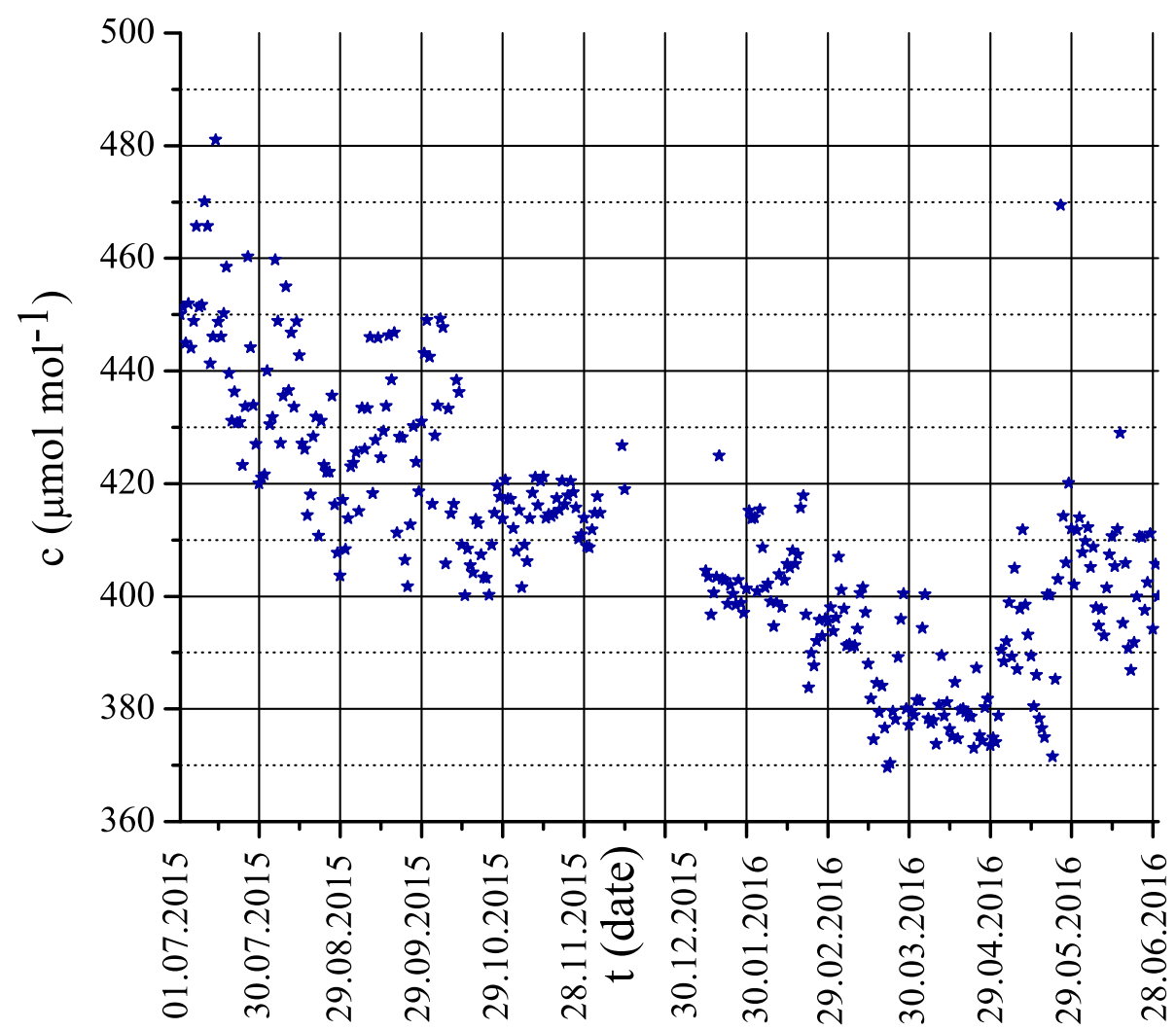

Figure 4. Observed daily averaged $\mathrm{CO}_{2}$ mole fraction during 1st July, 2015 to 30th June, 2016.

the dry period of winter, i.e., in the months of December, January and February not much of $\mathrm{CO}_{2}$ emission is observed from the soil. However, during pre-monsoon period, i.e., in the months on March, April and May LAI increases gradually signifying the growth of new leaves in the plants. As a result enhanced photosynthetic activity is observed bringing $c$ further down. Moreover, soil remains dry during this period. Hence, contribution of soil emission could also remain low in atmospheric $\mathrm{CO}_{2}$ concentration.

\subsection{Leaf Area Index (LAI)}

LAI is measured bi-weekly manually at KNP. This measurement frequency is recommended and followed by the scientific community (Walker et al. 2006) as LAI does not have fast modes of variability. However, the site being located far away it is very difficult to maintain this frequency. Hence, only 20 LAI measurements could be taken instead of 28 during 1st July, 2015 to 10th September, 2016 which are plotted in figure 5 . To obtain annual variation of LAI, a 9th order polynomial was fit to this. Each calendar day of the year was assigned a serial number starting from 1 for 1st January,
2015. As there are 365 days in 2015, 1st July, 2015 is assigned serial number 182 . On the other hand, 2016 is a leap-year having 366 days. Hence, 10th September, 2016 is assigned serial number 249. The new variable constructed this way is named 'day of year', abbreviated as DOY and used as independent variable for the polynomial fitting of LAI. This variable is also used for further analyses in this paper. Governing equation for this fit can be written as:

$$
\begin{aligned}
\mathrm{LAI}= & a_{1}+b_{11} \cdot \mathrm{DOY}+b_{12} \cdot \mathrm{DOY}^{2}+b_{13} \cdot \mathrm{DOY}^{3} \\
& +b_{14} \cdot \mathrm{DOY}^{4}+b_{15} \cdot \mathrm{DOY}^{5}+b_{16} \cdot \mathrm{DOY}^{6} \\
& +b_{17} \cdot \mathrm{DOY}^{7}+b_{18} \cdot \mathrm{DOY}^{8}+b_{19} \cdot \mathrm{DOY}^{9}
\end{aligned}
$$

This fit has been obtained by weighted least-square method in OriginPro 8. An adjusted $R^{2}$ value of 0.88 suggests the fit to be able to reproduce LAI variation with confidence during this period. This fit of LAI is also plotted in figure 5. More details about this fit including standard error (SE) for each of the fit coefficients are provided in table 2 .

For the entire period of our study, LAI was enhanced during the monsoon and reduced in winter. Subsequently, LAI showed increasing and 


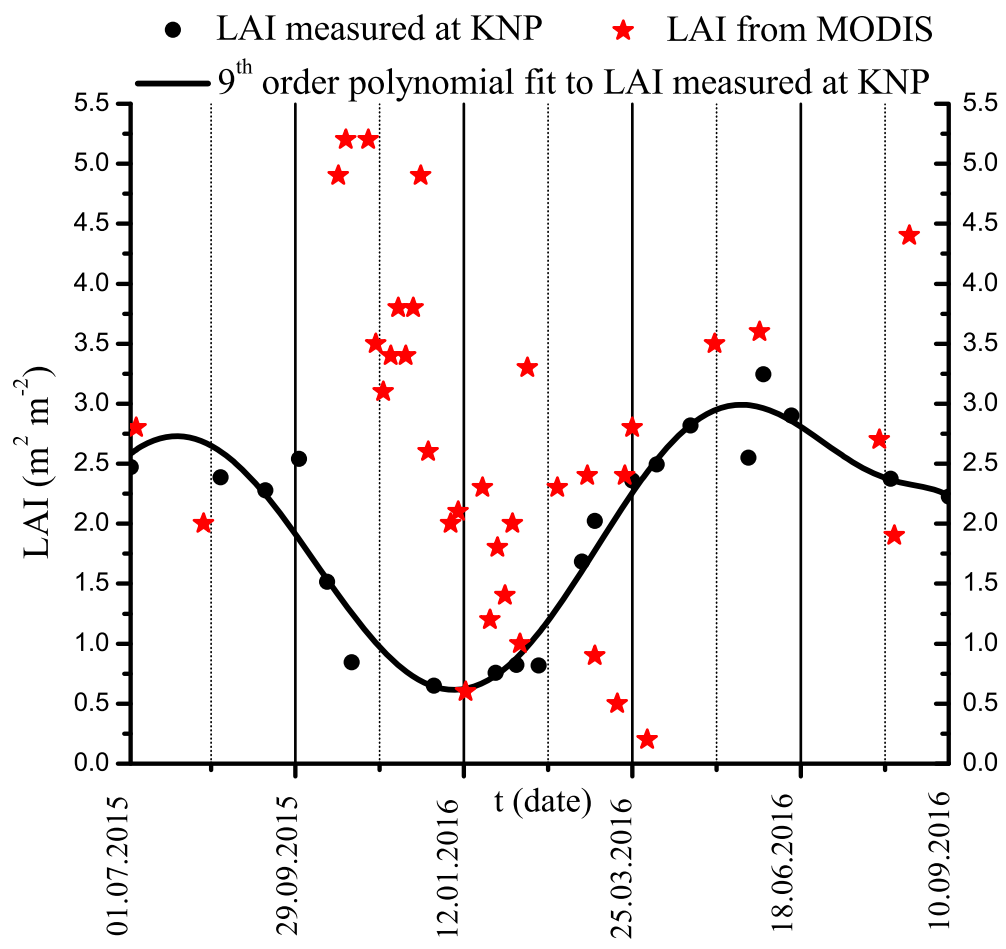

Figure 5. Measured, MODIS-derived and fit LAI during 1st July, 2015 to 10th September, 2016.

Table 2. Polynomial fit coefficients for LAI.

\begin{tabular}{lcc}
\hline $\begin{array}{l}\text { Fit coefficients } \\
\text { of LAI }\end{array}$ & Value & $\begin{array}{c}\text { Standard error } \\
(\mathrm{SE})\end{array}$ \\
\hline $\mathrm{a}_{1}$ & 0 & 0 \\
$\mathrm{~b}_{11}$ & $2.85 \times 10^{-14}$ & $3.29 \times 10^{-15}$ \\
$\mathrm{~b}_{12}$ & $3.85 \times 10^{-12}$ & $4.44 \times 10^{-13}$ \\
$\mathrm{~b}_{13}$ & $4.10 \times 10^{-10}$ & $4.74 \times 10^{-11}$ \\
$\mathrm{~b}_{14}$ & $2.64 \times 10^{-8}$ & $3.04 \times 10^{-9}$ \\
$\mathrm{~b}_{15}$ & $-2.73 \times 10^{-10}$ & $3.56 \times 10^{-11}$ \\
$\mathrm{~b}_{16}$ & $1.11 \times 10^{-12}$ & $1.63 \times 10^{-13}$ \\
$\mathrm{~b}_{17}$ & $-2.23 \times 10^{-15}$ & $3.65 \times 10^{-16}$ \\
$\mathrm{~b}_{18}$ & $2.21 \times 10^{-18}$ & $4.02 \times 10^{-19}$ \\
$\mathrm{~b}_{19}$ & $-8.62 \times 10^{-22}$ & $1.74 \times 10^{-22}$ \\
\hline
\end{tabular}

decreasing patterns during pre- and post-monsoon respectively. Minimum value of LAI was 0.75 in January, 2016. It reached a maximum value of 3.25 in June, 2016. Such type of LAI variation is typical of a deciduous forest (Saigusa et al. 2002) where leaf shedding is observed in winter. During post-monsoon, leaf senescence is observed followed by the abscission bringing the LAI down. On the other hand, rapid increase in LAI is seen during pre-monsoon due to the active plant physiological growth resulting in the formation of new leaves. In situ measured LAI has a smooth pattern of variation during the period of our study. However, few deviations are observed which need to be explained. First of these occur on 29th September, 2015 when LAI value is 2.5. It is more than the expected value of 2.0. Another such event is observed on 3rd June, 2016. LAI recorded on this day is 3.25 which is more than the expected value of 3.0. Explaining these gives the authors a good opportunity to let the readers of this article know a bit more about the site and the difficulties associated with it. During ISM, this region receives heavy amount of rainfall. As a result, the approach way to the site remains water-logged for months during and after ISM. Several feet of standing water makes the site inaccessible. However, LAI measurements are conducted despite these problems. According to our observation logbook, both of these days were very sunny. Moreover, as the sites were water-logged on both these days it took the observers longer than usual time to reach the measurement site via an alternate route. Due to these reasons, LAI measurements could only be conducted during noon time. All other measurements were taken during morning or afternoon. These are the times of the day when diffused sunlight is present in the atmosphere and hence recommended for conducting the LAI measurement by the scientific community (Bréda 2003; Ahl et al. 2006). However, on 29th November, 2015 and 3rd June, 2016, this condition could not be met and measurement was carried out 
with the Sun being overhead. Internal algorithm of LAI-2200 for retrieving LAI suffers difficulties in bright conditions (Aragão et al. 2005; Garrigues et al. 2008; Kobayashi et al. 2013) which might have led to the overestimation on these two days.

\subsection{Comparison between ground-based and MODIS LAI}

Quality controlled and filtered MODIS LAI data during 1st July, 2015 to 10th September, 2016 has also been plotted in figure 5. It is evident from the figure that the MODIS LAI has a pattern of variation similar to the in situ measurements. MODIS LAI shows a decreasing trend starting from the end of October, 2015 till the end of January, 2016. Following that an increasing trend is observed from the beginning of February till the end of May in 2016. It starts decreasing slowly from the end of June, 2016. Although this fashion of variation of MODIS LAI agrees largely with the variation of the in situ measured LAI, large variability is seen in the former. Maximum LAI recorded by the in situ measurement is 3.25 which is observed in June. However, MODIS has a significant discord with this value and its occurrence. It predicts a maximum LAI of 5.25 in October. MODIS predicts an LAI of 3.5 during June which is fairly comparable to the LAI estimate by in situ measurement around this time. In situ measurement of LAI shows minimum value to be 0.75 which occurs in January during winter. This is expected as the deciduous components of the canopy shed leaves in winter. MODIS LAI also records a similar value during this period. However, it has many abrupt and large fluctuations in winter and pre-monsoon seasons which seem to obscure the pattern of variation contained in the data. It has two unusually large deviations in the end of March and the beginning of April. These spikes report LAI value as low as 0.25 . This is much smaller than the minimum value observed in winter and hence seems to be unrealistic. Although MODIS LAI follows the decreasing and increasing trends in post-monsoon and pre-monsoon, absolute LAI values vary widely. Also the variation is much smoother in the ground-based in situ LAI measurement. MODIS seems to have a failure in capturing the vegetation dynamics during post-monsoon. It overestimates the LAI during this period, also in winter and pre-monsoon. However, it has lesser disagreement with in situ measured LAI in winter and pre-monsoon than in monsoon and postmonsoon. Pre-monsoon is the time of generation of new leaves in plants. Such overestimation of LAI over forest ecosystems can occur in the MODIS product in other locations also (Aragão et al. 2005; Garrigues et al. 2008). Ahl et al. (2006) showed that MODIS products could capture the general phenology of the canopy but overestimated the LAI during the absence of leaves quite similarly to our case. In another study by Garrigues et al. (2008), LAI is shown to be overestimated by MODIS for observed LAI values more than 4 . This is similar to our observation in June 2016 when LAI reported by MODIS is around 5.25 but the site-measured LAI is around 2.5. MODIS LAI is shown to have more error over Indian region by Tripathi et al. (2013).

This mismatch between ground-observed and MODIS LAI may result from a misrepresentation of vegetation canopy at KNP in MODIS algorithm. Since no such extensive study for validating MODIS biophysical parameters over north-east India exists before this study, it is difficult to identify the sources of error. A probable reason for the discrepancy in MODIS LAI during winter can also be the small solar zenith angle during this period (Huete et al. 2002; Fensholt et al. 2004).

\subsection{Modelling gross primary productivity (GPP)}

Observed variables have been used as the input parameters in ACM for predicting daily GPP at KNP. Additionally, ACM requires the following variables to run. Foliar Nitrogen $(\mathrm{N})$ concentration (nitro) is defined as the grams of $\mathrm{N}$ per square meter of leaf-area. No study has reported the nutrient contents of the plants at KNP till date. However, in an earlier work nitrogen contents for tropical dry deciduous and evergreen leaves were estimated to be $1.65 \mathrm{gN} \mathrm{m}^{-2}$ and $2.50 \mathrm{gN} \mathrm{m}^{-2}$ respectively (Zobel and Singh 1997). An extensive study on distributions of leaf mass, density and thickness of woody plants spread across multiple biomes were carried out by Niinemets (1999). It suggests mean Nitrogen content to be $1.79 \mathrm{gN} \mathrm{m}^{-2}$ with a standard deviation (SD) of $0.98 \mathrm{gN} \mathrm{m}^{-2}$. In our work, nitro has been set at $1.9 \mathrm{gN} \mathrm{m}^{-2}$. Hence, total foliar $\mathrm{N}$ concentration became $1.9 \times \mathrm{LAI} \mathrm{gN} \mathrm{m}^{-2}$.

Leaf-soil water potential difference $\left(\psi_{d}\right)$ is defined as the difference between canopy minimum leaf water potential and soil water potential (Williams et al. 1997). The more negative this parameter is, the more is the available water to the canopy. As described earlier in the introduction, KNP is located in north-east India. Annually this region 


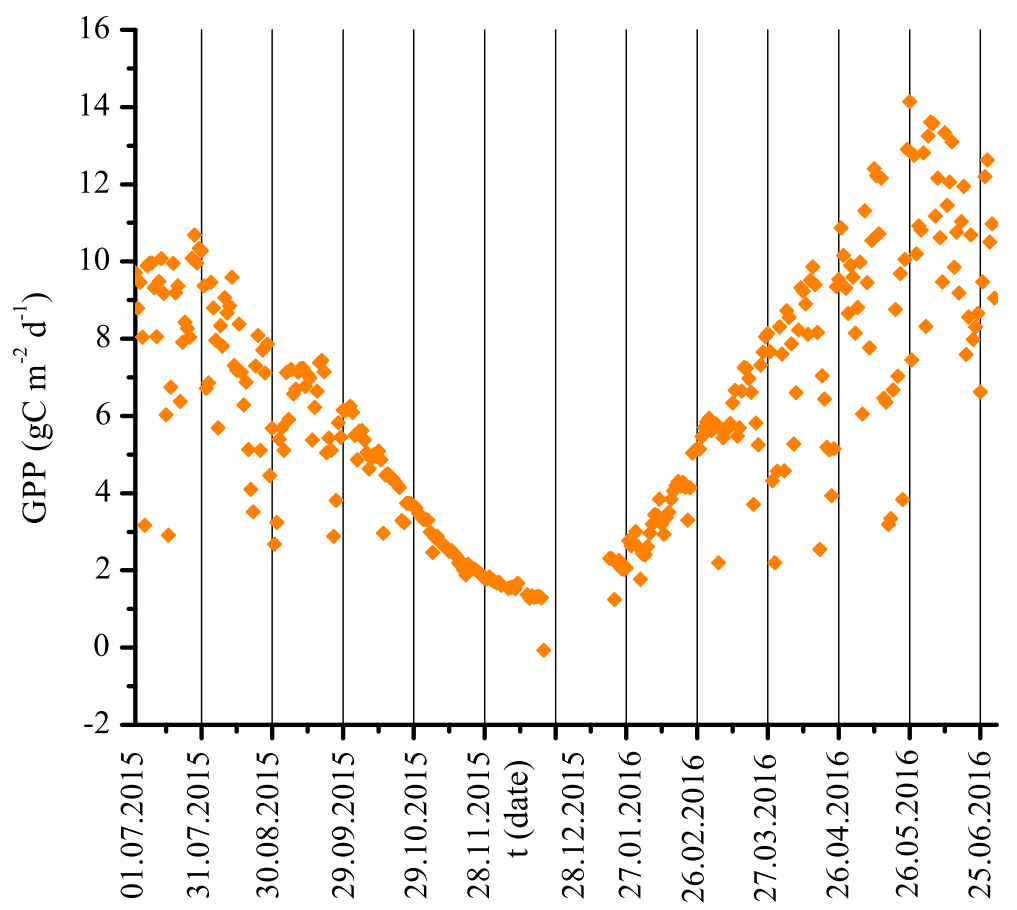

Figure 6. Modelled daily GPP using ACM during 1st July, 2015 to 30th June, 2016.

receives heavy amount of rainfall $(\sim 2346 \mathrm{~mm})$ (Jain et al. 2013). Forest floor inundation is also observed at several places. Hence, no water stress was assumed to be present and $\psi_{d}$ was set at $-2.5 \mathrm{MPa}$. Total plant-soil hydraulic resistance $\left(R_{\text {tot }}\right)$ is a coarse-scale agglomeration of fine-scale SPA model drivers. It is a combination of soil hydraulic resistance, root, leaf and stem dimensions (Williams et al. 1996). The more the canopy height, the more the $R_{\text {tot }}$. However, relative control of $R_{\text {tot }}$ on GPP is much lesser than other driving variables. Moreover, in well-watered or no droughtstress condition it becomes even less significant (Williams et al. 1997). In the present work, $R_{\text {tot }}$ has been set at $1.0 \mathrm{MPa} \mathrm{m}^{2} \mathrm{~s} \mathrm{mmol}^{-1}$. Calculated daily GPP have been plotted in figure 6 . There exists a gap of almost three weeks in observed GPP due to missing $\mathrm{CO}_{2}$ values as explained earlier. Hence to estimate annual variation of GPP, a 9th order polynomial was fit to the observed values which can be expressed mathematically as:

$$
\begin{aligned}
\mathrm{GPP}= & a_{2}+b_{21} \cdot \mathrm{DOY}+b_{22} \cdot \mathrm{DOY}^{2}+b_{23} \cdot \mathrm{DOY}^{3} \\
& +b_{24} \cdot \mathrm{DOY}^{4}+b_{25} \cdot \mathrm{DOY}^{5}+b_{26} \cdot \mathrm{DOY}^{6} \\
& +b_{27} \cdot \mathrm{DOY}^{7}+b_{28} \cdot \mathrm{DOY}^{8}+b_{29} \cdot \mathrm{DOY}^{9}
\end{aligned}
$$

Weighted least-square method was used in Origin Pro 8 for this above curve-fitting. Adjusted $R^{2}$ value for this fit is 0.74 suggesting the fit to be a good representation of annual GPP variation. This fit of GPP is plotted in figure 7. Details about this fit including standard error (SE) for each of the fit coefficients can be found in table 3 .

Fit of daily GPP was integrated to calculate annual GPP (figure 7). Period of the integration was kept as one year from 1st July, 2015 to 30th June, 2016. It was same as the period of the observation, as described earlier. Calculated this way, annual GPP turns out to be approximately equal to $2110 \mathrm{gC} \mathrm{m}^{-2}$ year $^{-1}$ or $2.11 \mathrm{kgC} \mathrm{m}^{-2}$ year $^{-1}$.

Daily GPP shows a well-defined pattern of annual variation. Maximum daily GPP is observed during monsoon. It decreases gradually during post-monsoon to a minimum in winter. It starts increasing in pre-monsoon before reaching maximum again in monsoon. From the polynomial fit, maximum daily GPP is seen to be $11.5 \mathrm{gC} \mathrm{m}^{-2} \mathrm{~d}^{-1}$ in June, 2016. It is minimum at $1.5 \mathrm{gC} \mathrm{m}^{-2} \mathrm{~d}^{-1}$ in December, 2015. Integrated GPP during July to September, 2015 is $750 \mathrm{gC} \mathrm{m}^{-2} \mathrm{~d}^{-1}$. At the end of February and June, 2016 integrated daily GPP are 1100 and $2100 \mathrm{gC} \mathrm{m}^{-2} \mathrm{~d}^{-1}$, respectively. Hence integration of daily GPP shows that cumulative daily GPP records rapid increments during monsoon and pre-monsoon and slower growths during post-monsoon and winter. In other words, probability of carbon sequestration is maximum during monsoon and pre-monsoon. Such a seasonal 


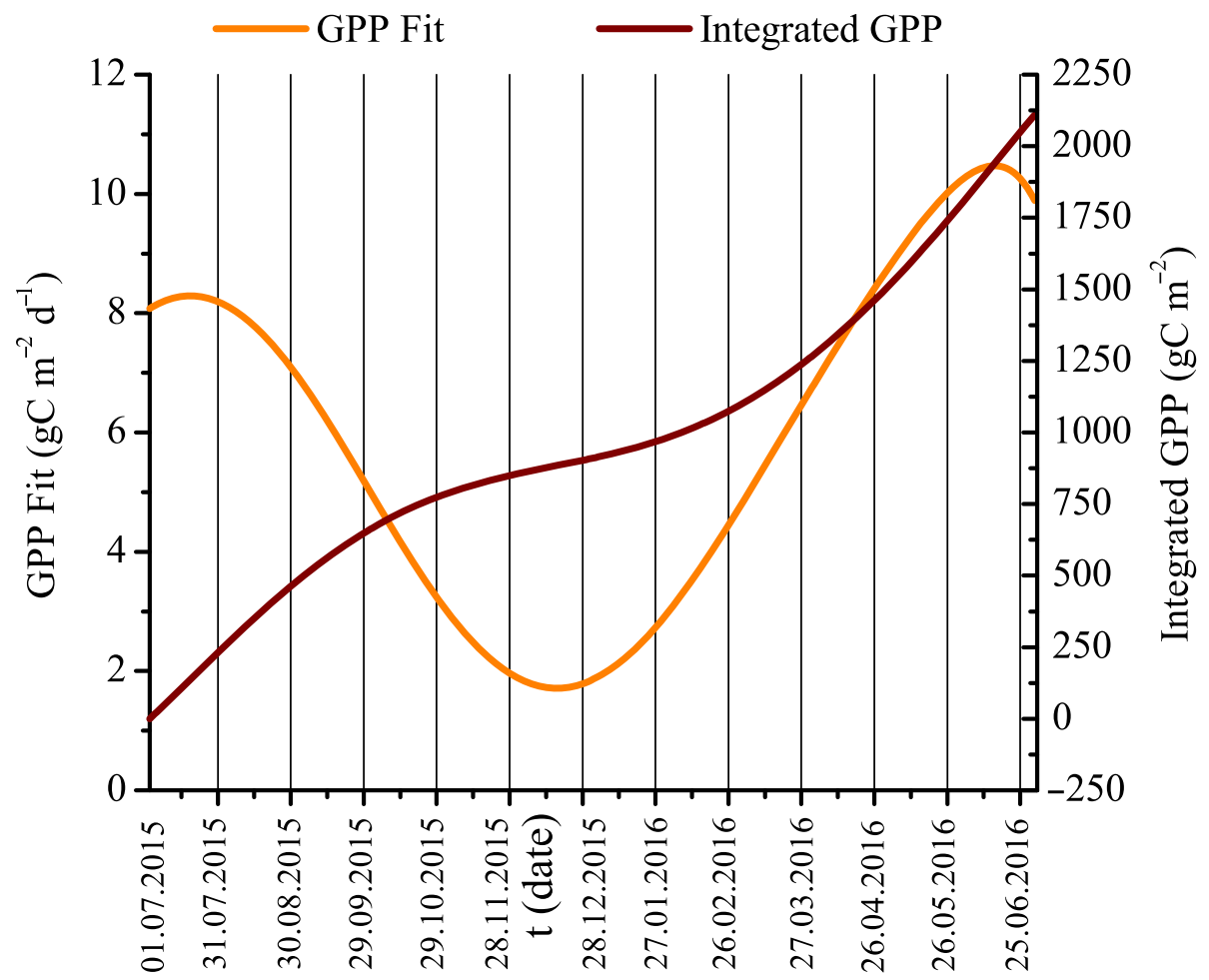

Figure 7. Polynomial fit to the modelled daily GPP and annual GPP calculated by integrating the fit during 1 st July, 2015 to 30 th June, 2016.

variation in plant productivity has been reported by Nayak et al. (2010). In this work, authors have modelled net primary productivity (NPP) over different ecosystems in India using satellite derived input data and a terrestrial biosphere model. This study shows that the onset of ISM by the end of June triggers an increase in NPP. According to this study, broadleaf deciduous and evergreen forests record second and third largest NPP over Indian landmass after croplands. However, it cannot be directly compared with our estimates due to two reasons. Firstly, NPP is a net estimate, whereas GPP is a gross one. Auto and heterotrophic respiration components need to be subtracted from GPP for calculating NPP. However, in the present work, respiration components are not calculated. Secondly, in the present work, in situ measurements of weather variables and LAI have been used for modelling GPP. Researchers have used satellite derived weather parameters and LAI also for modelling GPP and NPP (Barman et al. 2014; Verma et al. 2014). Satellite-based GPP and NPP products are also available as MOD17 product (Turner et al. 2003; Wang et al. 2013). However, either of these estimates tend to have bias compared to ground-based estimates and hence are less reliable as reported by many researchers (Heinsch et al. 2006; Liu et al. 2014; Neumann et al. 2006).
Table 3. Polynomial fit coefficients for GPP.

\begin{tabular}{lcc}
\hline $\begin{array}{l}\text { Fit coefficients } \\
\text { of GPP }\end{array}$ & Value & $\begin{array}{c}\text { Standard error } \\
(\mathrm{SE})\end{array}$ \\
\hline $\mathrm{a}_{2}$ & 0 & 0 \\
$\mathrm{~b}_{21}$ & $1.33 \times 10^{-13}$ & $1.06 \times 10^{-14}$ \\
$\mathrm{~b}_{22}$ & $1.68 \times 10^{-11}$ & $1.34 \times 10^{-12}$ \\
$\mathrm{~b}_{23}$ & $1.66 \times 10^{-9}$ & $1.31 \times 10^{-10}$ \\
$\mathrm{~b}_{24}$ & $9.75 \times 10^{-8}$ & $7.73 \times 10^{-9}$ \\
$\mathrm{~b}_{25}$ & $-1.07 \times 10^{-9}$ & $1.04 \times 10^{-10}$ \\
$\mathrm{~b}_{26}$ & $4.69 \times 10^{-12}$ & $5.44 \times 10^{-13}$ \\
$\mathrm{~b}_{27}$ & $-1.09 \times 10^{-14}$ & $1.40 \times 10^{-15}$ \\
$\mathrm{~b}_{28}$ & $1.11 \times 10^{-17}$ & $1.76 \times 10^{-18}$ \\
$\mathrm{~b}_{29}$ & $-4.77 \times 10^{-21}$ & $8.73 \times 10^{-22}$ \\
\hline
\end{tabular}

Annual GPP for multiple deciduous forests located in different climatic regions have been reported by many researchers (Goulden et al. 1996; Barford et al. 2001). For a cool temperate deciduous forest in Japan it was estimated to be $1.146 \mathrm{kgC} \mathrm{m}^{-2}$ year $^{-1}$ (Saigusa et al. 2002). Annual GPP for a temperate deciduous hardwood forest in north-eastern United States was calculated to be $1.639 \mathrm{kgC} \mathrm{m}^{-2}$ year $^{-1}$ (Turner et al. 2003). For a tropical semi-deciduous forest in Amazon basin El-Masri et al. (2013) simulated the same to be $2.66 \mathrm{kgC} \mathrm{m}^{-2}$ year $^{-1}$. However, due to unavailability of data very few of such studies exist for Indian 
forests. In one of such studies GPP was estimated to be $1.271 \mathrm{kgC} \mathrm{m}^{-2}$ year $^{-1}$ for a mangrove forest (Rodda et al. 2016) in Gangetic delta over Bay of Bengal. In our study annual GPP is estimated to be $2.11 \mathrm{kgC} \mathrm{m}^{-2}$ year $^{-1}$. This is similar to the predicted values by global modelling studies done by Barman et al. (2014). A global scale simulation for upscaling carbon and water fluxes done by Jung et al. (2011) using a machine learning technique Fluxnet-MTE (Model tree Ensemble) also predicts the similar value of GPP over KNP. Positive and negative values of GPP represent sinking and sourcing of carbon respectively. Hence our result indicates at the possibility of a large amount of carbon sequestration at annual scale at KNP. However, actual carbon sequestration will be less than GPP and can only be inferred from NPP which is an absolute measure of net carbon exchange between the atmosphere and the biosphere.

\section{Summary}

In the present work 1-year long observational records of LAI, air temperature, incoming shortwave radiation and atmospheric $\mathrm{CO}_{2}$ concentration measured by a micrometeorological flux tower over the forest ecosystem at Kaziranga National Park during July 2015-June 2016 have been presented. These variables have also been used as inputs in Aggregated Canopy Model for estimating the annual GPP of this forest ecosystem. This forest is identified as a semi-evergreen moist deciduous forest located in a humid sub-tropical environment. This is the very first time that the annual variation of LAI has been studied for a tropical forest ecosystem located in north-east India. The LAI is seen to vary between 0.75 in winter and 3.25 in summer. The ground-based in situ measured LAI is seen to capture the vegetation phenology in a more efficient way than MODIS. Annual GPP at Kaziranga National Park is estimated to be $2.11 \mathrm{kgC} \mathrm{m}^{-2}$ year $^{-1}$. This is also the very first time that carbon sequestration potential of any forest in north-east India has been studied. In this work GPP has been calculated using daily scale meteorological variables. No fine scale variable such as highfrequency flux has been used in this calculation.

Present work provides with the first ever groundbased LAI and GPP estimates from this part of the globe. This is expected to fill the gaps in data availability as well as scientific understanding of the vegetation dynamics from this region.
Specifically, this dataset will be immensely beneficial for the modelling community. The GPP estimate calculated in this work needs to be validated against the GPP calculated by upscaling the ground-based fluxes. Authors of the present paper plan to continue this study with further calculations of high frequency eddy covariance fluxes of $\mathrm{CO}_{2}$, water and energy. More micrometeorological flux towers are being established over different unique and pristine ecosystems in India under the aegis of the MetFlux India project. This is expected to generate a continuous long-term database of good quality climate and flux data over India in near future.

\section{Acknowledgements}

Our sincere gratitude to the Director, IITM for all his constant encouragement and support. We thank all the members of the project team for all possible help. CCCR (Centre for Climate Change Research) is part of Indian Institute of Tropical Meteorology, Pune (IITM) and is fully supported by the Earth System Science Organization (ESSO) of Ministry of Earth Sciences (MoES), Government of India. A special thanks to Dr. Stephan Matthiesen, GAUGE (Greenhouse gAs Uk and Global Emissions) UK for conducting International Summer School on global greenhouse gases in 2016 .

\section{References}

Ahl D E, Gower Stith T, Burrows S N, Shavanov N V, Myneni R B and Knyazikhin Y 2006 Monitoring spring canopy phenology of a deciduous broadleaf forest using MODIS; Remote Sens. Environ. 104 88-95.

Aragão L E O C, Shimabukuro Y E, Espirito-Santo F D B and Williams M 2005 Spatial validation of the collection 4 MODIS LAI product in Eastern Amazonia; IEEE Trans. Geosci. Rem. Sens. 43 2526-2534.

Baldocchi D, Falge E, Gu L and Olson R et al. 2001 FLUXNET: A new tool to study the temporal and spatial variability of ecosystem-scale carbon dioxide, water vapor, and energy flux densities; Bull. Am. Meteor. Soc. $822415-2434$.

Barford C C, Wofsy S C, Goulden M L, Munger J W, Pyle E H, Urbanski S P, Hutyra L, Saleska S R, Fitzjarrald D and Moore K 2001 Factors controlling long- and shortterm sequestration of atmospheric $\mathrm{CO}_{2}$ in a mid-latitude forest; Science 294 1688-1691.

Barman R, Jain A K and Liang M 2014 Climate-driven uncertainties in modeling terrestrial gross primary production: A site level to global-scale analysis; Global Change Biol. 20 1394-1411.

Beringer J, Hutley L B, McHugh I, Arndt S K, Campbell D, Cleugh H A, Cleverly J, Resco de Dios V, Eamus D and 
Evans B et al. 2016 An introduction to the Australian and New Zealand flux tower network - Ozflux; Biogeosci. 13 5895-5916.

Biudes M S, Machado N G, Danelichen V H D M, Souza M C, Vourlitis G L and Nogueira J D S 2014 Ground and remote sensing-based measurements of leaf area index in a transitional forest and seasonal flooded forest in Brazil; Int. J. Biometeorol. 58 1181-1193.

Boden T A, Krassovski M and Yang B 2013 The AmeriFlux data activity and data system: An evolving collection of data management techniques, tools, products and services; Geosci. Instrum. Methods Data Sys. 2 $165-176$.

Bonan G B 1995 Land-atmosphere $\mathrm{CO}_{2}$ exchange simulated by a land surface process model coupled to an atmospheric general; J. Geophys. Res. 100 2817-2831.

Bonan G B, Lawrence P J, Oleson K W, Levis S, Jung M, Reichstein M, Lawrence D M and Swenson S C 2011 Improving canopy processes in the Community Land Model version 4 (CLM4) using global flux fields empirically inferred from FLUXNET data; J. Geophys. Res.: Biogeosci. 116(G02014), doi: 10.1029/2010JG001593.

Bréda N J 2003 Ground-based measurements of leaf area index: A review of methods, instruments and current controversies; J. Exp. Bot. 54 2403-2417.

Chabra A and Dadhwal V K 2004 Estimating terrestrial net primary productivity over India using satellite data; Curr. Sci. 86 269-271.

Chapin III F S, Woodwell G M, Randerson J T, Rastetter E B, Lovett G M, Baldocchi D D, Clark D A, Harmon M E, Schimel D S and Valentini R et al. 2006 Reconciling carbon-cycle concepts, terminology, and methods; Ecosystems 9 1041-1050.

Chen J M, Govind A, Sonnentag O, Zhang Y, Barr A and Amiro B 2006 Leaf area index measurements at Fluxnet Canada forest sites; Agric. For. Meteorol. 140 257-268.

Coops N C, Black T A, Jassal R P S, Trofymow J T and Morgenstern K 2007 Comparison of MODIS, eddy covariance determined and physiologically modelled gross primary production (GPP) in a Douglas-fir forest stand; Remote Sens. Environ. 107 385-401.

Curtis P S, Hanson P J, Bolstad P, Barford C, Randolph J, Schmid H and Wilson K B 2002 Biometric and eddycovariance based estimates of annual carbon storage in five eastern North American deciduous forests; Agric. For. Meteorol. 113 3-19.

El-Masri B, Barman R, Meiyappan P, Song Y, Liang M and Jain A K 2013 Carbon dynamics in the Amazonian basin: Integration of eddy covariance and ecophysiological data with a land surface model; Agric. For. Meteorol. 182 156-167.

Fensholt R, Sandholt I and Rasmussen M S 2004 Evaluation of MODIS LAI, fAPAR and the relation between fAPAR and NDVI in a semi-arid environment using in situ measurements; Rem. Sens. Environ. 91 490-507.

Fisher J I and Mustard J F 2007 Cross-scalar satellite phenology from ground, Landsat, and MODIS data; Remote Sens. Environ. 109 261-273.

Fisher R A, Williams M, Do V, Lobo R, Costa A L D and Meir P 2006 Evidence from Amazonian forests is consistent with isohydric control of leaf water potential; Plant Cell Environ. 29 151-165.
Fisher R, Williams M, Costa D, Lola A, Malhi Y, Costa R D, Almeida S and Meir P 2007 The response of an eastern Amazonian rain forest to drought stress: Results and modelling analyses from a throughfall exclusion experiment; Global Change Biol. 13 2361-2378.

Gao F, Morisette J, Wolfe R E, Ederer G, Pedelty J, Masuoka E, Myneni R, Tan B and Nightingale J 2008 An algorithm to produce temporally and spatially continuous MODISLAI time series; IEEE Geosci. Remote Sens. Lett. 5 60-64.

Garbulsky M F, Peñuelas J, Papale D, Ardö J, Goulden M L, Kiely G, Richardson A D, Rotenberg E, Veenendaal E M and Filella I 2010 Patterns and controls of the variability of radiation use efficiency and primary productivity across terrestrial ecosystems; Global Ecol. Biogeogr. 19 253-267.

Garrigues S, Shabanov N V, Swanson K, Morisette J, Baret F and Myneni R B 2008 Intercomparison and sensitivity analysis of leaf area index retrievals from LAI-2000, AccuPAR, and digital hemispherical photography over croplands; Agric. For. Meteorol. 148 1193-1209.

Garrigues S, Lacaze R, Baret F J T M, Morisette J T, Weiss M, Nickeson J E, Fernandes R, Plummer S, Shavanov N V and Myneni R B et al. 2008 Validation and intercomparison of global leaf area index products derived from remote sensing data; J. Geophys. Res:. Biogeosci. 113(G02028), doi: 10.1029/2007JG000635.

Gitelson A A, Peng Y, Masek J G, Rundquist D C, Verma S, Suyker A, Baker J M, Hatfield J L and Meyers T 2012 Remote estimation of crop gross primary production with Landsat data; Remote Sens. Environ. 121 404-414.

Goulden M L, Munger J W, Fan S-M, Daube B C and Wofsy S C 1996 Exchange of carbon dioxide by a deciduous forest: Response to interannual climate variability; Science 271 1576-1578.

Gower S T, Kucharik C J and Norman J M 1999 Direct and indirect estimation of leaf area index, $\mathrm{f}_{A P A R}$, and net primary production of terrestrial ecosystems; Remote Sens. Environ. 70 29-51.

Grace J, Malhi Y, Lloyd J, McIntyre J, Miranda A C, Meir $\mathrm{P}$ and Miranda H S 1996 The use of eddy covariance to infer the net carbon dioxide uptake of Brazilian rain forest; Global Change Biol. 2 209-217.

Harper C W, Blair J M, Fay P A, Knapp A K and Carlisle J D 2005 Increased rainfall variability and reduced rainfall amount decreases soil $\mathrm{CO}_{2}$ flux in a grassland ecosystem; Global Change Biol. 11 322-334.

Heinsch F A, Zhao M, Running S W, Kimball J S, Nemani R, Davis K J, Bolstad P V, Cook B D, Desai A R and Ricciuto D M et al. 2006 Evaluation of remote sensing based terrestrial productivity from MODIS using regional tower eddy flux network observations; IEEE Trans. Geosci. Remote Sens. 7 1908-1925.

Huete A, Didan K, Miura T, Rodriguez E P, Gao X and Ferreira L G 2002 Overview of the radiometric and biophysical performance of the MODIS vegetation indices; Remote Sens. Environ. 83 195-213.

Jain S, Kumar V and Saharia M 2013 Analysis of rainfall and temperature trends in northeast India; Int. J. Climatol. 33 968-978.

Jha C S, Thumaty K C, Rodda S R, Sonakia A and Dadhwal V K 2013 Analysis of carbon dioxide, water vapour and energy fluxes over an Indian teak mixed 
deciduous forest for winter and summer months using eddy covariance technique; J. Earth Syst. Sci. 1221259 1268.

Jonckheere I, Fleck S, Nackaerts K, Muys B, Coppin P, Weiss $\mathrm{M}$ and Baret F 2004 Review of methods for in situ leaf area index determination. Part I: Theories, sensors and hemispherical photography; Agric. For. Meteorol. 121 19-35.

Jung M, Reichstein M, Margolis H A, Cescatti A, Richardson A D, Arain M A, Arneth A, Bernhofer C, Bonal D and Chen J et al. 2011 Global patterns of land-atmosphere fluxes of carbon dioxide, latent heat, and sensible heat derived from eddy covariance, satellite, and meteorological observations; J. Geophys. Res.: Biogeosci. 116(G00J07), doi: 10.1029/2010JG001566.

Kaimal J C and Finnigan J J 1994a Atmospheric Boundary Layer Flows: Their Structure and Measurement; United States of America Oxford University Press, pp. 264-266.

Kaimal J C and Finnigan J J 1994b Atmospheric Boundary Layer Flows: Their Structure and Measurement; United States of America Oxford University Press, pp. 234-240.

Knyazikhin Y, Martonchik J V, Myneni R B, Diner D J and Running S W 1998 Synergistic algorithm for estimating vegetation canopy leaf area index and fraction of absorbed photosynthetically active radiation from MODIS and MISR data; J. Geophys. Res. 103 32,25732,276 .

Kobayashi H, Ryu Y, Baldocchi D D, Welles J M and Norman J M 2013 On the correct estimation of gap fraction: How to remove scattered radiation in gap fraction measurements?; Agric. For. Meteorol. 174 170-183.

Le Quéré C, Raupach M R, Canadell J G, Marland G, Bopp L, Ciais P, Conway T J, Doney S C, Feely R A and Foster $\mathrm{P}$ et al. 2009 Trends in the sources and sinks of carbon dioxide; Nat. Geosci. 2 831-836.

Le Quéré C, Moriarty R, Andrew R M, Peters G P, Ciais G P, Friedlingstein P, Jones S D, Sitch S, Tans P and Arneth A et al. 2015 Global carbon budget 2014; Earth Syst. Sci. Data 7 47-85.

Liang L, Schwartz M D and Fei S 2011 Validating satellite phenology through ground observation and landscape scaling in a mixed seasonal forest; Remote Sens. Environ. $115143-157$.

Liu Z, Shao Q and Liu J 2014 The performances of MODISGPP and-ET products in China and their sensitivity to input data (FPAR/LAI); Remote Sens. 7 135-152.

Mizoguchi Y, Miyata A, Ohtani Y, Hirata R and Yuta S 2009 A review of tower flux observation sites in Asia; J. For. Res. 14 1-9.

Muraoka H, Saigusa N, Nasahara K N, Noda H, Yoshino J, Saitoh T M, Nagai S, Murayama S and Koizumi H 2010 Effects of seasonal and interannual variations in leaf photosynthesis and canopy leaf area index on gross primary production of a cool-temperate deciduous broadleaf forest in Takayama, Japan; J. Plant Res. 123 $563-576$

Myneni R B, Hoffman S, Knyazikhin Y, Privette J L, Glassy J, Tian Y, Wang Y, Song S, Zhang Y and Smith G R et al. 2002 Global products of vegetation leaf area and fraction absorbed PAR from year one of MODIS data; Remote Sens. Environ. 83 214-231.
Nayak R K, Patel N R and Dadhwal V K 2010 Estimation and analysis of terrestrial net primary productivity over India by remote-sensing-driven terrestrial biosphere model; Environ. Monit. Assess. 170 195-213.

Nayak R, Patel N and Dadhwal V K 2013 Inter-annual variability and climate control of terrestrial net primary productivity over India; Int. J. Climatol. 33 132-142.

Neumann M, Zhao M, Kinderman G and Hasenauer H 2015 Comparing MODIS net primary production estimates with terrestrial national forest inventory data in Austria; Remote Sens. 7 3878-3906.

Niinemets Ü 1999 Research review. Components of leaf dry mass per area - thickness and density - alter leaf photosynthetic capacity in reverse directions in woody plants; New Phytol. 144 35-47.

Patel N, Dadhwal V and Saha S 2011 Measurement and scaling of carbon dioxide $\left(\mathrm{CO}_{2}\right)$ exchanges in wheat using flux-tower and remote sensing; J. Indian Soc. Remote Sens. 39 383-391.

Rodda S R, Thumaty K C, Jha C S and Dadhwal V K 2016 Seasonal variations of carbon dioxide, water vapor and energy fluxes in tropical Indian mangroves; Forests 735.

Saigusa N, Yamamoto S, Murayama S and Kondo H 2005 Inter-annual variability of carbon budget components in an AsiaFlux forest site estimated by long-term flux measurements; Agric. For. Meteorol. 134 4-16.

Saigusa N, Yamamoto S, Murayama S, Kondo H and Nishimura N 2002 Gross primary production and net ecosystem exchange of a cool-temperate deciduous forest estimated by the eddy covariance method; Agric. For. Meteorol. 112 203-215.

Saikia A 2009 NDVI variability in northeast India; Scott. Geogr. J. 125 195-213.

Schaefer K, Schwalm C R, Williams C, Arain M A, Barr A, Chen J M, Davis K J, Dimitrov D, Hilton T W and Hollinger D Y et al. 2012 A model-data comparison of gross primary productivity: Results from the North American Carbon Program site synthesis; J. Geophys. Res.: Biogeosci. 117(G03010), doi: 10.1029/2012JG001960.

Schimel D S, House J I, Hibbard K A, Bousquet P, Ciais P, Peylin P, Braswell B H, Apps M J, Baker D and Bondeau A et al. 2001 Recent patterns and mechanisms of carbon exchange by terrestrial ecosystems; Nature $\mathbf{4 1 4}$ 169-172.

Sellers P, Dickinson R, Randall D, Betts A, Hall F, Berry J, Collatz G, Denning A, Mooney $\mathrm{H}$ and Nobre C et al. 1997 Modeling the exchanges of energy, water, and carbon between continents and the atmosphere; Science $\mathbf{2 7 5}$ 502-509.

Solberg S, Brunner A, Hanssen K H, Lange H, Næsset E, Rautiainen M and Stenberg P 2009 Mapping LAI in a Norway spruce forest using airborne laser scanning; Remote Sens. Environ. 113 2317-2327.

Sponseller R A 2007 Precipitation pulses and soil $\mathrm{CO}_{2}$ flux in a Sonoran desert ecosystem; Global Change Biol. 13 426-436.

Sundareshwar P, Murtugudde R, Srinivasan G, Singh S, Ramesh K, Ramesh R, Verma S, Agarwal D, Baldocchi $\mathrm{D}$ and Baru $\mathrm{C}$ et al. 2007 Environmental monitoring network for India; Science 316 204-205.

Takagi H, Saeki T, Oda T, Saito M, ValsalaV, Belikov D, Saito R, Yoshida Y, Morino I and Uchino O et al. 2011 
On the benefit of GOSAT observations to the estimation of regional $\mathrm{CO}_{2}$ fluxes; Sola 7 161-164.

Tang H, Brolly M, Zhao F, Strahler A H, Schaaf C L, Ganguly S, Zhang G and Dubayah R 2014 Deriving and validating Leaf Area Index (LAI) at multiple spatial scales through lidar remote sensing: A case study in Sierra National Forest, CA; Remote Sens. Environ. 143 131141.

Tripathi R, Sahoo R N, Gupta V K, Sehgal V K and Sahoo P M 2013 Retrieval of Leaf Area Index using IRS-P6, LISSIII data and validation of MODIS LAI product (MOD15 V5) over trans Gangetic Plains of India; Indian J. Agr. Sci 83 380-385.

Turner D P, Ritts W D, Cohen W B, Gower S T, Zhao M, Running S W, Wofsy S C, Urbanski S, Dunn A L and Munger J 2003 Scaling gross primary production (GPP) over boreal and deciduous forest landscapes in support of MODIS GPP product validation; Remote Sens. Environ. $88256-270$.

Valsala V, Tiwari Y K, Pillai P, Roxy M, Maksyutov S and Murtugudde R 2013 Intraseasonal variability of terrestrial biospheric $\mathrm{CO}_{2}$ fluxes over india during summer monsoons; J. Geophys. Res.: Biogeosci. 118 $752-769$.

Verma M, Friedl M A, Richardson A D, Kiely G, Law B E, Cescatti A, Wohlfart G, Gielen B, Roupsard O and Moors E J et al. 2014 Remote sensing of annual terrestrial gross primary productivity from MODIS: An assessment using the FLUXNET La Thuile dataset; Biogeosci. 11 21852200 .

Vickers D and Mahrt L 1997 Quality control and flux sampling problems for tower and aircraft data; J. Atmos. Ocean. Tech. 14 512-526.

Walker J, Robarge W, Wu Y and Meyers T 2006 Measurement of bi-directional ammonia fluxes over soybean using the modified Bowen-ratio technique; Agric. For. Meteorol. $13854-68$.

Wang X, Ma M, Li X, Song Y, Tan J, Huang G, Zhang Z, Zhao T, Feng J and Ma Z et al. 2013 Validation of MODIS-GPP product at 10 flux sites in northern China; Int. J. Remote Sens. 34 587-599.

Watham T, Kushwaha S, Patel N and Dadhwal V 2014 Monitoring of carbon dioxide and water vapour exchange over a young mixed forest plantation using eddy covariance technique; Curr. Sci. 107 857-867.

Watson D J 1947 Comparative physiological studies on the growth of field crops: I. Variation in net assimilation rate and leaf area between species and varieties, and within and between years; Ann. Bot. 11 41-76.

Williams M, Rastetter E, Fernandes D, Goulden M, Wofsy S, Shaver G, Melillo J, Munger J, Fan S M and Nadelhoffer K 1996 Modelling the soil-plant-atmosphere continuum in a Quercus-Acer stand at Harvard Forest: The regulation of stomatal conductance by light, nitrogen and soil/plant hydraulic properties; Plant Cell Environ. 19 911-927.

Williams M, Rastetter E B, Fernandes D N, Goulden M L, Shaver G R and Johnson L C 1997 Predicting gross primary productivity in terrestrial ecosystems; Ecol. Appl. 7 882-894.

Wu C, Chen J M and Huang N 2011 Predicting gross primary production from the enhanced vegetation index and photosynthetically active radiation: Evaluation and calibration; Remote Sens. Environ. 115 3424-3435.

Yang W, Tan B, Huang D, Rautiainen M, Shabanov N V, Wang Y, Privette J L, Huemmrich K F, Fensholt R and Sandholt I et al. 2006 MODIS leaf area index products: From validation to algorithm improvement; IEEE Trans. Geosci. Remote Sens. 44 1885-1898.

Zobel D B and Singh S P 1997 Himalayan forests and ecological generalizations; BioScience 47 735-745. 